\title{
MIR506 wt Allele
}

National Cancer Institute

\section{Source}

National Cancer Institute. MIR506 wt Allele. NCI Thesaurus. Code C134704.

Human MIR506 wild-type allele is located in the vicinity of Xq27.3 and is 124 bp in length.

This allele, which encodes MIR506 pre-miRNA, may play a role in the regulation of gene expression. 